\title{
Effect of fetal hypophysectomy on the initiation of parturition in the goat
}

\author{
N. C. Rawlings* and W. R. Ward \\ Department of Veterinary Clinical Studies, University of Liverpool, \\ Leahurst, Neston, Wirral, Merseyside, U.K.
}

\begin{abstract}
Summary. Fetal hypophysectomy performed between 97 and 130 days of gestation caused a significant $(P<0.005)$ prolongation of pregnancy in 5 goats in which every fetus was treated. Three of these goats gave birth spontaneously. Sham surgery or hypophysectomy of one fetus of twins had no effect on gestation length. Hypophysectomized kids, delivered after prolonged pregnancy, were significantly heavier than normal term kids $(P<0.005)$ and had lighter adrenals $(P<0.025)$. Measurements of maternal peripheral plasma concentrations of progesterone and total unconjugated oestrogens showed that the changes in goats carrying hypophysectomized fetuses were similar to those of normal pregnancy except that the prepartum oestrogen peak was absent, whether or not parturition occurred spontaneously.
\end{abstract}

\section{Introduction}

Early observations on prolonged pregnancy in sheep, cattle and man (for review see Holm, 1967) indicated the necessity of an intact pituitary-adrenal axis for normal parturition to occur at the expected time. Recent experimental work (for review see Liggins, 1973) on fetal hypophysectomy (Liggins, Kennedy \& Holm, 1968) and infusion of cortisol or corticotrophin to fetal lambs (Liggins, 1968) has identified the involvement of the fetal pituitary-adrenal axis in the initiation of parturition in the ewe. Less evidence is available to support a fetal role in the initiation of parturition in the goat, in which the source of progesterone during pregnancy is almost entirely the corpus luteum (Linzell \& Heap, 1966; Blom \& Lyngset, 1971). Van Rensburg (1965) showed that habitual abortion in Angora goats was due to hyperplasia of the fetal adrenal and Thorburn, Nicol, Bassett, Shutt \& Cox (1972) induced premature parturition by infusion of ACTH to the fetus.

The purpose of the present study was to assess the importance of the fetal goat pituitary for the normal onset of parturition, by hypophysectomizing fetuses in utero during the last third of pregnancy. An attempt was also made to monitor circulatory hormonal changes in the goats carrying hypophysectomized fetuses.

\section{Materials and Methods}

Laparotomy was performed under halothane anaesthesia after induction with thiopentone sodium ( $100 \mathrm{mg} / 9 \mathrm{~kg}$ body weight) on 11 multiparous goats (9 Saanen and 2 Anglo-Nubian) between Days 97 and 130 of gestation. An electrode $2 \mathrm{~mm}$ in diameter and insulated, except for the lower $5 \mathrm{~mm}$, was introduced through the frontal bone of the fetal cranium (Liggins et al., 1968). The positioning of the fetal head within the fetal membranes and uterine wall, for introduction of the electrode, was achieved by using the stereotaxic instrument described by Comline, Silver \& Silver (1970). The contents of the sella turcica were destroyed by passing a diathermy current for $10-20 \mathrm{sec}$. The electrode was then withdrawn $5 \mathrm{~mm}$ and the cautery repeated to ensure destruction of the pituitary stalk. In 8 nannies (Nos 1-8), all fetuses were hypophysectomized; one carrying twins (No. 6) and 2 carrying single fetuses

* Present address: Department of Veterinary Physiological Sciences, College of Veterinary Sciences, University of Saskatchewan, Saskatoon, Saskatchewan, Canada S7N 0W0. 
(Nos 7 and 8 ) aborted within $48 \mathrm{~h}$ of surgery. The number of fetuses carried by Nos $1-5$ is given in Table 2. In a further 2 nannies (Nos 9 and 10), only one fetus of twins was treated and one nanny (No. 11), carrying a single fetus, was subjected to laparotomy and uterine handling only.

All 11 goats undergoing surgery and 7 unoperated goats (carrying 1-3 fetuses each) were bled daily by venepuncture to determine the temporal pattern of maternal plasma concentrations of progesterone and total unconjugated oestrogens in late pregnancy. The radioimmunoassays used to measure progesterone and total unconjugated oestrogens in plasma from goats and ewes have been described previously (Rawlings \& Ward, 1976): the sensitivities of the assays were $10 \mathrm{pg}$ progesterone/ $\mathrm{ml}$ and $5 \mathrm{pg}$ unconjugated oestrogens/assay tube. The inter-assay variations were $17 \cdot 2 \pm 2 \cdot 0 \%(n=37)$ and $16.0 \pm 0.9 \%(n=92)$, respectively.

At parturition all the kids from Goats $1-5$ and 10 normal intact kids (described in Table 1) were killed and weighed and the adrenals were removed and weighed. A median section of the head was made and the sella turcica and hypothalamic region was dissected and examined macroscopically. The results were assessed by analysis of variance.

\section{Results}

The sham surgery in Goat 11 and the hypophysectomy of only one of twin fetuses in Goats 9 and 10 had no effect on the length of gestation or prepartum endocrine changes. The endocrine data from these 3 goats have therefore been combined with those of the unoperated control goats. The mean gestation length for Goats 1-5 carrying hypophysectomized fetuses was $160 \cdot 00 \pm 2 \cdot 39$ (s.e.m.) days and was significantly longer $(P<0.005)$ than for the control goats $(148 \pm 1.46$ days). Goats 3,4 and 5 eventually gave birth spontaneously after pregnancies lasting 162,154 and 157 days respectively. The pregnancies of Goats 1 and 2 were terminated by Caesarean section at 168 and 159 days of gestation, respectively, because of rapidly developing hydramnios. The hypophysectomized fetuses were very weak, or recently dead, when inspected at birth or Caesarean delivery (see Table 2).

Examination of the heads revealed complete destruction of the pituitary gland. In all cases the sella was empty at examination, apart from some dry and some liquefied necrotic material hanging from the walls; no connection to the brain was seen. An attempt was made to fix and stain this material, but no viable tissue was found and severe difficulty was encountered in the handling of these remains. Cautery damage was evident on the walls of the sella and the tract of the electrode was obvious in the hypothalamus and more superior regions. Although the hypothalamic region was not examined histologically, the gross appearance of this tissue was of charred, necrotic tissue, in an area of 6-8 mm diameter around the tract of the electrode, extending for 1-2 cm towards the frontal bone.

Table 1. Body weight, adrenal weight and ratio of adrenal over body weight for hypophysectomized and normal intact kids at birth or Caesarean delivery

\begin{tabular}{llccc}
\hline Dam no. & Sex of kid & $\begin{array}{c}\text { Body wt } \\
(\mathrm{kg})\end{array}$ & $\begin{array}{c}\text { Adrenal wt } \\
(\mathrm{g})\end{array}$ & $\begin{array}{c}\text { Adrenal wt/ } \\
\text { body wt }\end{array}$ \\
\hline Hypophysectomized kids & & & & \\
1 & Male & 3.83 & 0.07 & 0.03 \\
1 & Female & $4 \cdot 80$ & 0.12 & 0.02 \\
2 & Male & $4 \cdot 75$ & 0.10 & 0.02 \\
2 & Male & $4 \cdot 19$ & 0.11 & 0.03 \\
3 & Female & 3.97 & $0 \cdot 14$ & 0.03 \\
3 & Female & 3.93 & 0.19 & 0.05 \\
4 & Male & $4 \cdot 12$ & 0.27 & 0.07 \\
5 & Female & $3 \cdot 85$ & 0.12 & 0.03 \\
5 & Female & 3.96 & 0.13 & 0.03 \\
Mean \pm s.e.m. & & $4 \cdot 10 \pm 0.12^{*}$ & $0.14 \pm 0.02^{* *}$ & $0.03 \pm 0.00^{*}$ \\
Normal kids $\dagger$ & & $2.58 \pm 0.18$ & $0.24 \pm 0.03$ & $0.10 \pm 0.01$ \\
Mean \pm s.e.m. & & &
\end{tabular}

Significantly different from normal kids, ${ }^{*} P<0.005,{ }^{* *} P<0.025$.

$\uparrow$ Three pairs of mixed sex twins and 4 singletons $(20,20)=10$ kids. 
Table 2. Concentrations of progesterone and total unconjugated oestrogens ( $\mathrm{ng} / \mathrm{ml}$ ) in maternal jugular plasma of goats in late pregnancy and bearing hypophysectomized fetuses

\begin{tabular}{|c|c|c|c|c|c|c|c|c|c|c|}
\hline \multirow{2}{*}{$\begin{array}{l}\text { Day of } \\
\text { gestation }\end{array}$} & \multicolumn{5}{|c|}{ Oestrogen } & \multicolumn{5}{|c|}{ Progesterone } \\
\hline & Goat 1 & Goat 2 & Goat 3 & Goat 4 & Goat 5 & Goat 1 & Goat 2 & Goat 3 & Goat 4 & Goat 5 \\
\hline 129 & $1 \cdot 04$ & $1 \cdot 28$ & - & 0.79 & - & - & $9 \cdot 23$ & - & - & - \\
\hline 130 & - & - & 1.53 & - & - & - & - & $7 \cdot 14$ & $5 \cdot 50$ & - \\
\hline 131 & - & - & - & - & - & $10 \cdot 69$ & - & - & - & - \\
\hline 132 & 0.89 & $1 \cdot 37$ & - & 0.94 & 0.75 & - & $5 \cdot 51$ & - & - & $7 \cdot 50$ \\
\hline 133 & - & - & 1.25 & - & - & - & - & $5 \cdot 44$ & 9.95 & - \\
\hline 134 & - & - & - & - & - & $7 \cdot 76$ & - & - & 一 & - \\
\hline 135 & 1.02 & 1.28 & - & 0.96 & 0.85 & - & 4.87 & - & - & $7 \cdot 10$ \\
\hline 136 & - & - & 1.62 & - & - & - & - & $5 \cdot 23$ & $6 \cdot 18$ & - \\
\hline 137 & - & - & - & - & - & $7 \cdot 42$ & - & - & - & - \\
\hline 138 & 0.60 & 1.57 & - & 0.74 & - & - & $6 \cdot 67$ & 6.46 & - & - \\
\hline 139 & - & - & 1.54 & - & 0.92 & $7 \cdot 33$ & - & - & $6 \cdot 12$ & $6 \cdot 50$ \\
\hline 140 & 1.49 & - & 1.52 & 0.91 & - & - & - & 5.71 & - & - \\
\hline 141 & 1.41 & $1 \cdot 25$ & 1.63 & 0.82 & - & $7 \cdot 34$ & 4.58 & - & 5.83 & - \\
\hline 142 & - & 1.25 & $1 \cdot 60$ & 0.86 & 1.06 & - & $5 \cdot 72$ & $5 \cdot 39$ & - & $6 \cdot 40$ \\
\hline 143 & 1.35 & $1 \cdot 27$ & $2 \cdot 20$ & 1.01 & - & $10 \cdot 06$ & 5.83 & - & $4 \cdot 20$ & - \\
\hline 144 & $1 \cdot 23$ & - & $2 \cdot 51$ & 0.89 & - & - & - & $7 \cdot 32$ & 一 & 一 \\
\hline 145 & 1.34 & $1 \cdot 17$ & 2.09 & 1.05 & 0.95 & $4 \cdot 51$ & $4 \cdot 47$ & - & 5.91 & - \\
\hline 146 & $1 \cdot 16$ & 1.41 & 1.87 & 1.41 & $1 \cdot 11$ & - & $5 \cdot 12$ & 5.67 & - & $6 \cdot 00$ \\
\hline 147 & - & 1.39 & $2 \cdot 01$ & 1.05 & 0.96 & $4 \cdot 31$ & 6.77 & $5 \cdot 34$ & 5.39 & - \\
\hline 148 & - & - & 1.95 & - & 0.82 & - & - & - & - & $5 \cdot 20$ \\
\hline 149 & 1.23 & 1.76 & 2.09 & 0.93 & 0.96 & $2 \cdot 74$ & $8 \cdot 36$ & 5.62 & 4.58 & - \\
\hline 150 & - & - & - & - & 0.77 & - & - & - & - & 4.40 \\
\hline 151 & - & - & - & - & 0.83 & $4 \cdot 77$ & 2.58 & 3.93 & 2.99 & $5 \cdot 60$ \\
\hline 152 & 1.08 & - & 1.84 & 1.03 & 0.81 & - & - & - & - & 9.20 \\
\hline 153 & - & 1.41 & - & $1 \cdot 14$ & 0.88 & 7.57 & 4.74 & - & 1.71 & - \\
\hline 154 & $\rightarrow$ & - & - & $0 \cdot 04$ & 0.77 & - & - & - & 0.06 & 5.00 \\
\hline 155 & 1.25 & - & 1.79 & - & 0.63 & 1.86 & 5.44 & 3.73 & - & $4 \cdot 20$ \\
\hline 156 & - & 1.56 & 1.88 & - & 0.56 & - & 3.34 & - & - & 1.20 \\
\hline 157 & - & 1.65 & $2 \cdot 12$ & - & 0.22 & $2 \cdot 67$ & $5 \cdot 18$ & 4.04 & - & 0.40 \\
\hline 158 & 1.99 & $1 \cdot 31$ & $2 \cdot 11$ & -- & - & - & $4 \cdot 58$ & - & - & \\
\hline 159 & - & 0.63 & 1.69 & - & - & 2.64 & - & 2.57 & - & \\
\hline 160 & - & - & 0.18 & - & - & - & - & 0.06 & - & \\
\hline 161 & 1.62 & & $2 \cdot 75$ & & & 1.48 & & 1.63 & & \\
\hline 162 & - & & 0.27 & & & - & & 0.33 & & \\
\hline 163 & - & & & & & 5.59 & & & & \\
\hline 164 & 1.63 & & & & & - & & & & \\
\hline 165 & - & & & & & 2.04 & & & & \\
\hline 166 & 1.65 & & & & & - & & & & \\
\hline 167 & 1.75 & & & & & $1 \cdot 15$ & & & & \\
\hline 168 & 0.44 & & & & & $2 \cdot 12$ & & & & \\
\hline
\end{tabular}

Goats 1 and 2 were delivered of twin fetuses by Caesarean section at Days 168 and 159. Goats 3 (twins), 4 (singleton) and 5 (twins) gave birth spontaneously to very weak or recently dead young.

As can be seen from Table 1, the mean body weight of the hypophysectomized kids from prolonged pregnancies was much heavier than that of the normal term kids. The hypophysectomized kids showed signs of postmaturity (hair growth, eruption of teeth). Mean adrenal weights for the hypophysectomized kids were significantly lower than those of the normal kids and the difference was even greater if the adrenal weights were expressed as a ratio of body weight.

The maternal concentrations of progesterone and oestrogens during late pregnancy in the 10 goats experiencing normal parturition at term are shown in Text-fig. 1, while the values for the goats in which all fetuses were hypophysectomized (Nos 1-5) are given in Table 2. In Goats 1-5, concentrations of progesterone were variable but within the limits for normal goats in late pregnancy. In Goats 3, 4 and 5, which gave birth spontaneously, plasma concentrations of progesterone declined before delivery in a manner similar to that in control goats. Plasma concentrations of total oestrogens 


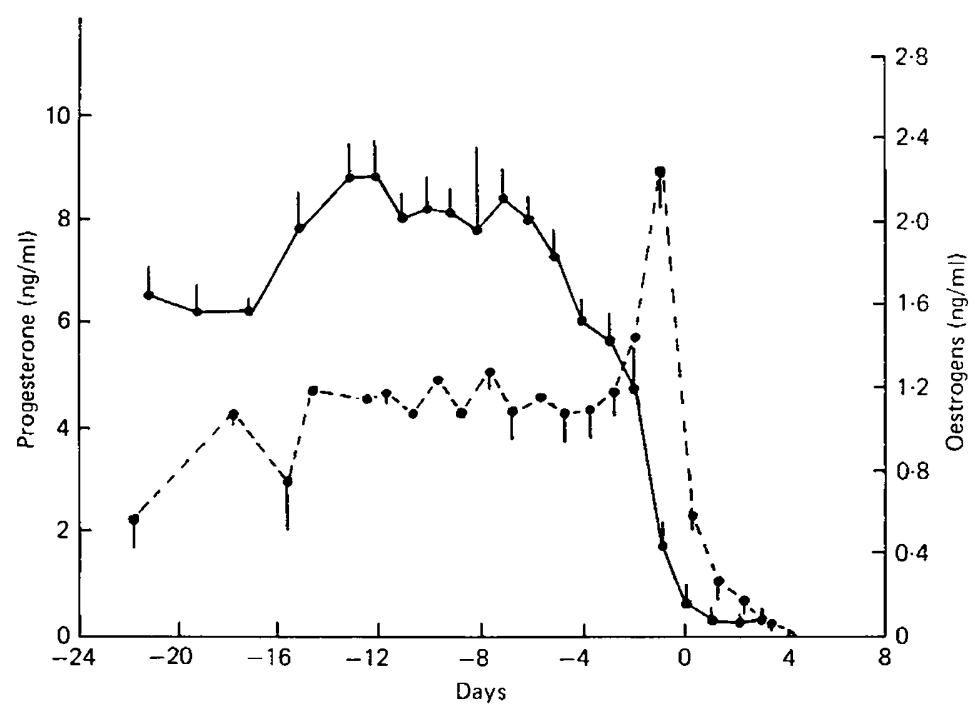

Text-fig. 1. Mean \pm s.e.m. concentrations of progesterone (-) and total unconjugated oestrogens (-- in the jugular plasma of 10 goats during the 24 days before normal parturition at term (Day 0 ).

were maintained after fetal hypophysectomy (Table 2) and were similar to those of the normal goats, but there was no prepartum peak as in the latter (Text-fig. 1).

\section{Discussion}

These results demonstrate that fetal hypophysectomy, performed between Days 107 to 125 of pregnancy, significantly delays parturition in the goat. It was necessary to hypophysectomize all of the fetuses present in any goat; if one kid of twins was left intact, parturition occurred at the expected time. As in sheep (Liggins et al., 1968), therefore, the fetal pituitary gland seems to be essential for the initiation of parturition at normal term. Liggins et al. (1968) concluded, from macroscopic examination of sagittal sections of the sella, that at least $70 \%$ of the fetal pituitary had to be destroyed to prolong pregnancy significantly. In the present study, all the fetuses were believed to be completely hypophysectomized. Some tissue may have survived in the medial basal hypothalamic, median eminence and upper pituitary stalk regions, but this was considered unlikely in view of the severe cautery employed. No attempt was made to measure fetal plasma concentrations of cortisol or ACTH at delivery, as it was felt that such values would be elevated by stress and placental disruption. The necessity of the ovine fetal adrenal for the onset of normal parturition has been demonstrated (Drost \& Holm, 1968) and infusions of cortisol and corticotrophin to the ovine fetus will induce parturition (Liggins, 1968). It is probable that the caprine fetal adrenal is also essential for the initiation of parturition at term because infusion of Synacthen to the fetal goat will induce parturition (Thorburn $e t$ al., 1972). The weight range and difference in size of the adrenals from normal term goat fetuses and hypophysectomized fetuses resembles that for sheep (Liggins et al., 1968; Comline et al., 1970). As observed in the present study on goats, the adrenal weights of control and completely hypophysectomized sheep fetuses showed some overlap (Comline et al., 1970).

The changes in maternal peripheral plasma concentrations of progesterone and oestrogens in the goats that gave birth normally at term in the present study resemble those observed by previous workers (Challis \& Linzell, 1971; Irving, Jones \& Knifton, 1972; Thorburn \& Schneider, 1972). Fetal hypophysectomy did not alter the maternal progesterone and oestrogen concentrations before Day 145 of gestation, but there was no consistent rise in oestrogen levels before parturition, even in animals giving birth spontaneously. Progesterone levels in nannies carrying hypophysectomized fetuses and giving birth spontaneously fell before parturition. When goats are hysterectomized in early pregnancy (before Day 49), the corpus luteum continues to secrete progesterone until Days 
147-184 of pregnancy (Currie \& Thorburn, 1974). This period encompasses the gestation lengths of the operated goats in the present study and it seems possible that the corpus luteum of pregnancy has a finite, albeit variable, lifespan, which, in the absence of a more positive mechanism, would eventually terminate pregnancy. An intrinsic failure of the corpus luteum, supported by the decline in progesterone levels, could explain the spontaneous parturition of the goats bearing hypophysectomized fetuses. In each case one or all of the fetuses were born dead, and had, according to the state of the fetuses and their membranes and fluids, died soon before birth. When pregnancy is maintained beyond term in ovariectomized goats by progesterone administration, parturition occurs following progesterone withdrawal and resembles that seen in the present study (Rawlings \& Ward, 1977).

In progesterone-treated ovariectomized goats (Rawlings \& Ward, 1977) maternal concentrations of oestrogens were elevated above control levels for 3-8 days during the period before parturition. Maternal plasma concentrations of oestrogens also rose during the induction of parturition in the goat, by fetal infusion of Synacthen (Thorburn et al., 1972). It therefore appears that one of the results of the fetal signal for parturition at normal term is an increase in concentration of oestrogens in maternal plasma. A body of evidence now exists to suggest that normal parturition at term in the goat is initiated by prostaglandin-induced luteolysis (Thorburn et al., 1972; Currie \& Thorburn, 1973; Currie, Wong, Cox \& Thorburn, 1793; Umo, Fitzpatrick \& Ward, 1976). It has been suggested that the elevated maternal plasma concentrations of oestrogen seen at term could stimulate prostaglandin release (Thorburn et al., 1972). The results of the present study, and from experiments involving the initiation of parturition by fetal infusion of Synacthen (Thorburn et al., 1972), strongly implicate a role for the fetal pituitary-adrenal axis in the initiation of parturition in the goat. The absence of a sharp elevation in plasma oestrogen concentration before parturition in goats carrying hypophysectomized fetuses, the amplification of this peak in pregnancies prolonged by progesterone (Rawlings \& Ward, 1977) and its presence at spontaneous and induced parturition (Thorburn et al., 1972), suggest that the fetal pituitary-adrenal axis may regulate the oestrogen peak. Oestrogens may stimulate uterine activity directly or cause the release of the luteolysin, prostaglandin F-2 $\alpha$. The nature of the modulation of maternal plasma oestrogen concentrations before parturition by the fetal pituitaryadrenal axis requires further research.

The oestrogen antiserum (No. SLC-10C) was a gift of Dr B. V. Caldwell (Yale University, U.S.A.), and the progesterone antiserum (No. 465/4-5) was a gift of Dr B. J. A. Furr (N.I.R.D., Reading). We thank Mr J. Cox who performed the anaesthesia and Mrs A. Gillette for technical assistance. The work was supported in part by a grant from the Medical Research Council.

\section{References}

Blom, A.K. \& LyngSet, O. (1971) Plasma progesterone levels in goats during pregnancy measured by competitive protein binding assay. Acta endocr., Copenh. 66, 471-477.

Challis, J.R.G. \& Linzell, J.L. (1971) The concentration of total unconjugated oestrogens in the plasma of pregnant goats. J. Reprod. Fert. 26, 401404.

Comline, R.S., Silver, M. \& Silver, I.A. (1970) Effect of fetal hypophysectomy on catecholamine levels in the lamb adrenal during prolonged gestation. Nature, Lond. 225, 739-740.

Currie, W.B. \& Thorburn, G.D. (1973) Induction of premature parturition in goats by prostaglandin $\mathbf{F}_{2 \alpha}$ administered into the uterine vein. Prostaglandins 4 , 201-204.

CURRIe, W.B. \& Thorburn, G.D. (1974) Luteal function in hysterectomized goats. J. Reprod. Fert. 41, 501504.
Currie, W.B., Wong, M.S.F., Cox, R.I. \& Thorburn, G.D. (1973) Spontaneous or dexamethasone induced parturition in the sheep and goat : changes in maternal prostaglandin $F$ and fetal oestrogen sulphate concentrations. Mem. Soc. Endocr. 20, 95-118.

Drost, M. \& HoLm, L.W. (1968) Prolonged gestation in ewes after fetal adrenalectomy. $J$. Endocr. 40, 293296.

Holm, L.W. (1967) Prolonged pregnancy. Adv. vet. Sci. 11, 159-205.

Irving, G., Jones, D.E. \& Knifton, A. (1972) Progesterone concentration in the peripheral plasma of pregnant goats after ovariectomy and replacement therapy. Res. vet. Sci. 13, 301-303.

Liggins, G.C. (1968) Premature parturition after infusion of corticotrophin or cortisol into fetal lambs. J. Endocr. 42, 323-329.

Liggins, G.C. (1973) Fetal participation in the physiological controlling mechanisms of parturition. In 
Fetal and Neonatal Physiology, pp. 562-572 (Sir Joseph Barcroft Centenary Symposium). Eds R. S. Comline, K. W. Cross, G. S. Dawes \& P. W. Nathanielsz. Cambridge University Press.

Liggins, G.C., Kennedy P.C. \& Holm, L.W. (1968) Failure of initiation of parturition after electro coagulation of the pituitary of the fetal lamb. Am. J. Obstet. Gynec. 98, 1080-1086.

Linzell, J.L. \& HeAP, R.B. (1966) Progesterone production by the ovary and adrenal and uptake by the mammary gland and uterus in the goat. J. Endocr. 35, xxiv.

RaWlings, N.C. \& WaRD, W.R. (1976) Changes in steroid hormones in plasma and myometrium and uterine activity in ewes during late pregnancy and parturition. J. Reprod. Fert. 48, 355-360.

RaWlings, N.C. \& WARD, W.R. (1977) Progesterone and the initiation of parturition in the goat. Theriogenology 7, 317-329.

Thorburn, G.D. \& SChNeIder, W. (1972) The progesterone concentration in the plasma of the goat during the oestrous cycle and pregnancy. $J$. Endocr. 52, 2336.

ThorbuRn, G.D., Nicol, D.H., Bassett, J.M., ShutT, D.A. \& Cox, R.I. (1972) Parturition in the goat and sheep: changes in corticosteroids, progesterone, oestrogens and prostaglandin F. J. Reprod. Fert., Suppl. 16, 61-84.

Umo, I., FitzPatrick, R.J. \& WARD, W.R. (1976) Parturition in the goat: plasma concentrations of prostaglandin $\mathrm{F}$ and steroid hormones and uterine activity during late pregnancy and parturition. $J$. Endocr. 68, 383-389.

VAN RENSBURG, S.J. (1965) Adrenal function and fertility. J. S. Afr. vet. med. Ass. 36, 491-500.

Received 30 May 1977 